\title{
An aldose reductase inhibitor prevents glucose-induced increase in transforming growth factor- $\beta$ and protein kinase $C$ activity in cultured human mesangial cells
}

\author{
H. Ishii, H. Tada, S. Isogai \\ Second Department of Internal Medicine, Toho University School of Medicine, Tokyo, Japan
}

\begin{abstract}
Summary We investigated the effect of inhibition of a polyol pathway on the glucose-induced increase in transforming growth factor- $\beta$ (TGF- $\beta$ ) production and activity of protein kinase $\mathrm{C}$ (PKC) in cultured human mesangial cells (MCs). The exposure of MCs to $33 \mathrm{mmol} / \mathrm{l}$ glucose resulted in an increase in TGF- $\beta$ production, measured by ELISA, compared with $5 \mathrm{mmol} / \mathrm{l}$ glucose. The glucose-induced increase in TGF- $\beta$ was prevented by concomitant incubation with epalrestat, an aldose reductase inhibitor (ARI), in a dose-dependent manner at a concentration of more than $10^{-6} \mathrm{~mol} / \mathrm{l}$. Moreover, the glucose-induced enhancement of PKC activity in the membrane fraction of MCs was also abolished by epalrestat. The ad-
\end{abstract}

dition of epalrestat to MCs cultured with $5 \mathrm{mmol} / \mathrm{l}$ glucose showed no demonstrable effects on TGF- $\beta$ production and PKC activity. These results provide direct evidence for linkages between derangements in polyol pathway and glucose-induced overproduction of TGF- $\beta$ and enhancement of PKC activity in MCs. Accordingly, the effect of an ARI on these metabolic abnormalities in MCs may justify its clinical application for treatment of diabetic nephropathy. [Diabetologia (1998) 41: 362-364]

Keywords Aldose reductase inhibitor, mesangial cells, TGF- $\beta$, protein kinase $\mathrm{C}$, high glucose concentration.
Diabetic nephropathy is a leading cause of morbidity and mortality in diabetes mellitus. Since diabetic glomerulopathy is characterized by an expansion of glomerular mesangium that eventually progresses to obliterate the capillary lumen, mesangial cells (MCs) are thought to play a central role in the pathogenesis of diabetic nephropathy. Elevated glucose levels appear to initiate MC dysfunction, probably via metabolic abnormalities such as derangements in polyol pathway [1], increased activity of protein kinase $\mathrm{C}$

Received: 27 October 1997

and in revised form: 25 November 1997

Corresponding author: Dr. H. Tada, Second Department of Internal Medicine, Toho University, 6-11-1 Ohmorinishi, Ohtaku, Tokyo 143, Japan

Abbreviations: MC, Mesangial cell; $\mathrm{PKC}$, protein kinase $\mathrm{C}$; TGF- $\beta$, transforming growth factor- $\beta$; ARI, aldose reductase inhibitor; FCS, fetal calf serum; PDBu, phorbol 12, 13 dibutyrate; DAG, diacylglycerol.
(PKC) $[2,3]$, and increased production of transforming growth factor- $\beta$ (TGF- $\beta$ ) [4]. However, the interaction between these metabolic abnormalities is unclear. To clarify this, we investigated whether inhibition of the polyol pathway by an aldose reductase inhibitor (ARI) could prevent the glucose-induced increase in the production of TGF- $\beta$ and the activity of $\mathrm{PKC}$ in cultured human MCs.

\section{Materials and methods}

Human MCs were cultured as previously reported [5]. A single cell line between the third and eighth passages was employed in this study. RPMI-1640 medium (GIBCO BRL, Gaithersburg, Md., USA) containing $20 \%$ fetal calf serum (FCS) was supplemented with either 5 or $33 \mathrm{mmol} / \mathrm{l}$ glucose in the presence $\left(10^{-8} \sim 5 \times 10^{-5} \mathrm{~mol} / \mathrm{l}\right)$ or absence of epalrestat. Medium supplemented with $5 \mathrm{mmol} / \mathrm{l}$ glucose $+28 \mathrm{mmol} / \mathrm{l} \mathrm{manni-}$ tol was used as an osmotic control. Since our preliminary experiments showed that incubating MCs with $33 \mathrm{mmol} / \mathrm{l} \mathrm{glu}-$ cose for 6 days resulted in a greater increase in TGF- $\beta$ pro- 
duction than that for 3 days, MCs were cultured in these different experimental media for 6 days. The culture media were exchanged at $24 \mathrm{~h}$ intervals. At the end of the incubation, the cells were incubated for another $24 \mathrm{~h}$ with the FCSfree experimental media to avoid the interference of FCS in the following assays. In addition, to investigate the effect of phorbol 12,13 dibutyrate (PDBu) on TGF- $\beta$ production from MCs, confluent MCs were incubated with $0.1 \mu \mathrm{mol} / 1 \mathrm{PDBu}$ for $6 \mathrm{~h}$.

For the assay of TGF- $\beta$, the culture supernatants were collected and were converted to the active form by treating the media with $\mathrm{HCl}$ (final concentration $0.2 \mathrm{~mol} / \mathrm{l}$ ) for $30 \mathrm{~min}$ at room temperature followed by neutralization with equimolar $\mathrm{NaOH}$. TGF- $\beta$ was determined with a quantitative sandwich enzyme immunoassay using TGF- $\beta$ soluble receptor type II (R \& D System Inc., Minneapolis, Minn., USA). Human recombinant TGF- $\beta 1$ was used as a standard.

For the assay of PKC activity, both membrane and cytosolic fractions were obtained by the method previously described [3]. PKC activity was measured using the kit. Pep Tag Non-Radioactive Assay for PKC (Promega, Madison, Wis., USA). This assay uses brightly coloured fluorescent peptide substrates (amino acid sequence, D-L-S-R-T-L-S-V-A-A-K) that are highly specific for PKC. Phosphorylation by PKC of their specific substrate alters the peptide's net charge from +1 to -1 . The phosphorylated version was separated by an agarose gel at $\mathrm{pH}$ 8.0. Negatively charged bands from the gel were removed and heated at $95^{\circ} \mathrm{C}$ until the gel slice was melted. Absorbance of the solubilized solution was read by a spectrophotometer at $570 \mathrm{~nm}$. Active rat PKC was used as a standard.

The DNA content in MCs was measured fluorometrically using the 33258 Hoechst dye binding methods.

Statistical analysis. Results are expressed as mean \pm SD. Statistical analysis were performed using Bonferroni's multiple comparison procedure.

\section{Results}

As shown in Figure 1, the addition of $10^{-5} \mathrm{~mol} / \mathrm{l}$ epalrestat to the culture had no effect on the amount of TGF- $\beta$ secreted from MCs grown in $5 \mathrm{mmol} / \mathrm{l}$ glucose. Exposure of MCs to $33 \mathrm{mmol} / \mathrm{l}$ glucose resulted in a significant $(p<0.01)$ increase in TGF- $\beta(124.4 \pm$ $10.2 \mathrm{pg} / \mu \mathrm{gDNA} / 24 \mathrm{~h})$ compared with $5 \mathrm{mmol} / \mathrm{l} \mathrm{glu}-$ cose $(104.3 \pm 6.6 \mathrm{pg} / \mu \mathrm{gDNA} / 24 \mathrm{~h})$. Incubating MCs with $5 \mathrm{mmol} / \mathrm{l}$ glucose $+28 \mathrm{mmol} / 1$ mannitol had no effect on TGF- $\beta$ production. When $10^{-8}, 10^{-7}, 10^{-6}$, $10^{-5}$ and $5 \times 10^{-5} \mathrm{~mol} / \mathrm{l}$ epalrestat were added to the

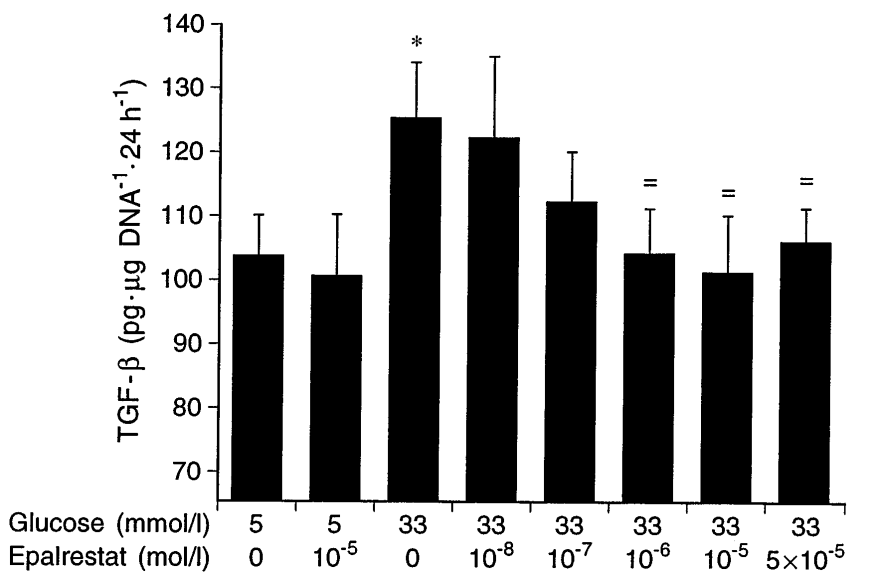

Fig. 1. Effect of glucose and epalrestat on TGF- $\beta$ production in human mesangial cells. Mesangial cells were cultured with 5 and $33 \mathrm{mmol} / \mathrm{l}$ glucose containing various doses $\left(0 \sim 5 \times 10^{-5}\right.$ $\mathrm{mol} / \mathrm{l}$ ) of epalrestat for 6 days. The amount of TGF- $\beta$ was measured by ELISA in the conditioned media obtained by another $24 \mathrm{~h}$-incubation. Data are the mean \pm SD of 6-12 experiments. $* p<0.01$ vs $5 \mathrm{mmol} / \mathrm{l}$ glucose in the absence of epalrestat; $\# p<0.01$ vs $33 \mathrm{mmol} / \mathrm{l}$ glucose in the absence of epalrestat

high-glucose media, the amounts of TGF- $\beta$ secreted into the medium were $121.8 \pm 14.0,112.8 \pm 8.0$, $104.0 \pm 7.1,101.1 \pm 8.2$ and $106.8 \pm 5.1 \mathrm{pg} / \mu \mathrm{gDNA} /$ $24 \mathrm{~h}$, respectively. Thus, the glucose-induced increase in the production of TGF- $\beta$ was totally prevented by epalrestat, in a dose-dependent manner, at a concentration more than $10^{-6} \mathrm{~mol} / \mathrm{l}$. The addition of $0.1 \mu \mathrm{mol} / 1 \mathrm{PDBu}$ resulted in a 1.9 -fold increase in TGF- $\beta$ production from MCs.

Incubation of MCs with $10^{-5} \mathrm{~mol} / \mathrm{l}$ epalrestat in $5 \mathrm{mmol} / \mathrm{l}$ glucose-medium had no effect on the PKC activity in the membrane fraction. Increasing glucose levels from 5 to $33 \mathrm{mmol} / \mathrm{l}$ for 6 days caused a significant $(p<0.01)$ increase in PKC activity in membrane fraction. Addition of epalrestat to the high-glucose medium resulted in a significant $(p<0.01)$ reduction in the PKC activity in membrane fraction. On the other hand, no significant differences were observed in PKC activity in cytosolic fraction among four groups (Table 1).

Table 1. Effect of glucose and epalrestat on PKC activity in human mesangial cells

\begin{tabular}{lll}
\hline & $\begin{array}{l}\text { Membrane fraction } \\
\mu \mathrm{mol} \cdot \mathrm{min}^{-1} \cdot \mu \mathrm{gDNA}^{-1}\end{array}$ & $\begin{array}{l}\text { Cytosolic fraction } \\
\mu \mathrm{mol}^{-} \mathrm{min}^{-1} \cdot \mu \mathrm{gDNA}^{-1}\end{array}$ \\
\hline $5 \mathrm{mmol} / \mathrm{l}$ glucose & $30.2 \pm 2.8$ & $34.8 \pm 8.0$ \\
$5 \mathrm{mmol} / \mathrm{l}$ glucose $+10^{-5} \mathrm{~mol} / \mathrm{l}$ epalrestat & $30.7 \pm 4.4$ & $35.0 \pm 4.4$ \\
$33 \mathrm{mmol} / \mathrm{l}$ glucose & $38.3 \pm 2.6^{\mathrm{a}}$ & $34.2 \pm 7.6$ \\
$33 \mathrm{mmol} / \mathrm{glucose}+10^{-5} \mathrm{~mol} / \mathrm{l}$ epalrestat & $33.2 \pm 2.6^{\mathrm{b}}$ & $38.4 \pm 7.2$ \\
\hline
\end{tabular}

Mesangial cells were grown in 5 and $33 \mathrm{mmol} / \mathrm{l}$ glucose in the presence or absence of $10^{-5} \mathrm{~mol} / \mathrm{l}$ epalrestat for 6 days. PKC activities in both membrane and cytosolic fractions were mea- sured as described in the Methods. Data are the mean \pm SD of 6 experiments

${ }^{\mathrm{a}} p<0.01$ vs $5 \mathrm{mmol} / \mathrm{l}$ glucose; ${ }^{\mathrm{b}} p<0.01$ vs $33 \mathrm{mmol} / \mathrm{l}$ glucose 


\section{Discussion}

It has been suggested that metabolic abnormalities in MCs induced by a high ambient glucose involve enhanced polyol pathway [3], increased diacylglycerol (DAG)-PKC pathway [2,3] and upregulation of TGF- $\beta$ [4]. These metabolic derangements have been shown to cause mesangial cell dysfunctions such as increased production of extracellular matrix, decreased degradation of extracellular matrix and cell hypertrophy, leading to mesangial expansion. So far, the linkage between these factors has not been clarified. In this study the glucose-induced increases in both production of TGF- $\beta$ and activity of PKC were abolished in MCs by an ARI. We have reported that the increase in sorbitol accumulation in cultured MCs exposed to a high glucose medium was completely prevented by $10^{-5} \mathrm{~mol} / \mathrm{l}$ epalrestat without having cytotoxicity to MCs [6], implying that an ARI used in the present study indeed inhibited the polyol pathway. These observations for the first time provide direct evidence of the linkages between polyol pathway and PKC activity as well as TGF- $\beta$ production.

We also observed that TGF- $\beta$ production was remarkably stimulated by $0.1 \mu \mathrm{mol} / 1 \mathrm{PDBu}$. This finding suggests that TGF- $\beta$ production is directly mediated by PKC. Therefore, it seems that ARI prevents glucose-induced upregulation of TGF- $\beta$ probably via suppressing $\mathrm{PKC}$ activation. On the other hand, it has been speculated that an increased cytosolic $\mathrm{NADH} / \mathrm{NAD}^{+}$resulting from enhanced polyol pathway may increase in de novo synthesis of DAG, followed by activation of PKC [7]. However, the precise mechanism through which ARIs prevent increased PKC activity remains to be explored.

An ARI has been reported to correct glomerular hyperfiltration and albuminuria in diabetic rats as well as human diabetic patients $[8,9]$. The concentra- tion of epalrestat in culture media used in this study is similar to that seen in the human serum when epalrestat was given by an oral administration (Ono Pharmaceutical Co., Ltd., personal data). Therefore, the findings that an ARI ameliorates glucose-induced metabolic abnormalities in MCs may warrant clinical trials for the treatment of diabetic nephropathy.

\section{References}

1. Kikkawa R, Umemura K, Haneda M, Arimura T, Ebata K, Shigeta Y (1987) Evidence for existence of polyol pathway in cultured rat mesangial cells. Diabetes 36: 240-243

2. Ayo SH, Radnik R, Garoni JA, Troyer DA, Kreisberg JI (1991) High glucose increases diacylcerol mass and activates protein kinase $\mathrm{C}$ in mesangial cell cultures. Am J Physiol 261: F571-F577

3. Kikkawa R, Haneda M, Uzu T, Koya D, Sugimoto T, Shigeta Y (1994) Translocation of protein kinase $\mathrm{C} \alpha$ and $\zeta$ in rat glomerular mesangial cells cultured under high glucose conditions. Diabetologia 37: 838-841

4. Wolf G, Sharma K, Chen Y, Ericksen M, Ziyadeh FN (1992) High glucose-induced proliferation in mesangial cells is reversed by autocrine TGF- $\beta$. Kidney Int 42: 647-656

5. Tada H, Ishii H, Isogai S (1997) Protective effect of D- $\alpha$-tocopherol on the function of human mesangial cells exposed to high glucose concentrations. Metabolism 46: 779-784

6. Tada H (1994) Mesangial cell dysfunction induced by a high glucose concentration. In: Uchiyama M, Asami T, Hayakawa $\mathrm{H}$ (eds) Current topics of glomerular mesangial cells. Kohko-do, Niigata, Japan, pp 75-84

7. Williamson J, Chang K, Frangos M et al. (1993) Hyperglycemic pseudohypoxia and diabetic complications. Diabetes 42 : 801-813

8. McCaleb ML, McKean ML, Hohman TC, Laver N, Robinson Jr WG (1991) Intervention with the aldose reductase inhibitor, tolrestat, in renal and retinal lesions of streptozotocin-diabetic rats. Diabetologia 34: 695-701

9. Passariello N, Pisano MCA, Sepe J et al. (1993) Effect of aldose reductase inhibitor (tolrestat) on urinary albumin excretion rate and glomerular filtration rate in IDDM subjects with nephropathy. Diabetes Care 16: 789-795 